\title{
MIR372 Gene
}

National Cancer Institute

\section{Source}

National Cancer Institute. MIR372 Gene. NCI Thesaurus. Code C81805.

This gene is involved in the regulation of gene expression and acts as an oncogene in non-small cell lung carcinoma and testicular germ cell tumors. 